\title{
Mycoplasmas and rheumatoid arthritis
}

\author{
SHEILA M. STEWART, J. J. R. DUTHIE, J. M. K. MACKAY, \\ B. P. MARMION, AND W. R. M. ALEXANDER* \\ From the Department of Bacteriology, University of Edinburgh, and the Rheumatic Diseases Unit, Northern \\ General Hospital, Edinburgh
}

The view that rheumatoid arthritis may have an infective aetiology dates from the 1930s at least, and enjoys a fluctuating popularity. It is based on some similarities between rheumatoid arthritis and diseases known to be caused by infective agents (Hill, 1968; Ford, 1963, 1968; Lancet, 1970; Buchanan and Dick, 1972) or on the similarity of the pathological changes in human rheumatoid arthritis compared with those in arthritis of animals known to be caused by mycoplasmas (Sabin, 1939a,b; Sharp, 1964; Sharp and Riggs, 1967; Ross and Switzer, 1968). The response of mycoplasmal arthritis in mice (Sabin and Warren, 1940; British Medical Journal, 1965) and of rheumatoid arthritis in man (Ford, 1968) to treatment with gold salts has been taken as suggesting a mycoplasmal cause of the latter disease. Recent work (Smiley, Sachs, and Ziff, 1968) has shown a substantial local, committed, synthesis of immunoglobulins in the synovium, but the nature of the stimulating antigen is unknown.

Many attempts have been made to isolate mycoplasmas from specimens of synovial fluid or synovial membrane from patients with rheumatoid arthritis. A summary of some attempts over the last 12 years is shown in Table I. It will be seen that results were variable, sometimes with higher isolation rates from non-RA cases or controls. Those series with high rates of isolation in cell-free media are Fahlberg, and others (1966), Williams (1968), Marcolongo and others, (1969), and Jansson and others (1971a,b). Other workers used cell culture inoculation as a preliminary step to cultivation on cell-free media. Williams (1968) identified his isolates as strains of Mycoplasma fermentans, and Jansson and her co-workers (1971a) showed their small-colony mycoplasmas to be related serologically to Mycoplasma arthritidis.

The existence of the more striking positive reports made it imperative to try and repeat the results. The present report describes a series of attempts to isolate mycoplasma from specimens of rheumatoid synovial membrane and synovial fluid over a period of 8 years from 1964 to 1972 . A wide variety of techniques and media was used.

\section{Materials}

The synovial fluids were collected at the Rheumatic Diseases Unit, Northern General Hospital, Edinburgh. The specimens of synovial membrane were taken at operation at the Princess Margaret Rose Hospital, Edinburgh. Patients were considered to have rheumatoid arthritis if they fulfilled the criteria of the American Rheumatism Association (1959), with or without the demonstration of rheumatoid factor in the serum. 176 patients with rheumatoid arthritis were examined; in 108 the sensitized sheep cell test was positive, and in 56 it was negative; in twelve the test had not been carried out. Any patients with 'doubtful' rheumatoid arthritis or juvenile rheumatoid arthritis have been excluded. Control material from 47 patients with non-rheumatoid conditions included specimens of normal synovial membrane removed at meniscectomy (fourteen patients); membrane removed from two patients with osteoarthrosis and one with osteochondritis; also synovial fluids from nineteen patients with osteoarthrosis, four with psoriatic arthropathy, three with polymyalgia rheumatica, one with intermittent hydrarthrosis, one with rheumatic fever, one with ankylosing spondylitis, and one with erythema nodosum. Lastly, 15 fluids from twelve patients with Reiter's disease were examined.

\section{Methods}

The synovial fluids were mostly inoculated into media in the undiluted form; in the majority of experiments large sampling volumes were used, but in some, dilutions of the fluids were also inoculated. The synovial membranes were originally homogenized by a mechanical blender, but were later minced finely with sterile instruments before being added to the appropriate medium.

The technique consisted of culturing the clinical samples in various liquid or semi-solid media, with or without inhibitors, and then subculturing onto supplemented PPLO agar. Some preparations were also inoculated directly onto supplemented PPLO agar. Some sets of specimens were cultured aerobically, some anaerobically, and some in $10 \% \mathrm{CO}_{2}$ in air. Specimens in series 1 were incubated for 8 weeks before being discarded as negative; in later series this period was reduced to 3 weeks, except for series 4 in which the plates were incubated for 6 weeks.

The liquid media used were the following:

(a) Eagle-Hanks tryptose phosphate broth (Mackay, 1966).

Accepted for publication December 17, 1973. 
(b) Supplemented semi-solid PPLO agar (Stewart and Chowdray, 1968).

(c) Supplemented PPLO broth at $\times 2$ normal concentration to allow the addition of an equal quantity of synovial fluid (Stewart, Alexander, and Duthie, 1969).

(d) As (c) but with the addition of $2 \%(\mathrm{w} / \mathrm{v}) \mathrm{NaCl}$ to detect possible L-forms (Stewart and others, 1969).

(e) Heated blood broth (Stewart and others, 1969). (f) Bullock heart broth (based on Williams, 1968) with supplements as for $(c)$ but at half concentrations.

(g) Diphasic medium prepared from single strength PPLO broth/agar supplemented as for (c) but at half strength and with the addition of $20 \%(\mathrm{v} / \mathrm{v})$ of a pancreatic digest of bovine lung (S. M. Stewart, unpublished data).

(h) Bovine heart infusion broth and agar (Jansson, 1971) which included $1 \%(v / v)$ pasteurized egg yolk.

Table I Reports of the isolation of mycoplasmas from patients with rheumatoid arthritis, Reiter's syndrome, and from control materials

\begin{tabular}{|c|c|c|c|c|c|}
\hline Reference & $\begin{array}{l}\text { Isolation } \\
\text { method }\end{array}$ & Specimen* & Diagnosis $\dagger$ & $\begin{array}{l}\text { Isolation } \\
\text { rate } \ddagger\end{array}$ & $\begin{array}{l}\text { Identity of } \\
\text { mycoplasma }\end{array}$ \\
\hline Jonsson (1961) & $\begin{array}{l}\text { Cell free (CF) } \\
\text { culture }\end{array}$ & $\begin{array}{l}\text { S/F } \\
\text { S/F }\end{array}$ & $\begin{array}{l}\text { RA } \\
\text { Control }\end{array}$ & $\begin{array}{r}0 / 12 \\
12 / 25\end{array}$ & $\overline{\text { Unidentified }}$ \\
\hline Arai, Ishikawa, and Hotta (1964) & CF culture & $\begin{array}{l}\mathbf{S} / \mathbf{F} \\
\mathbf{S} / \mathbf{F}\end{array}$ & $\begin{array}{l}\text { RA } \\
\text { Control }\end{array}$ & $\begin{array}{l}8 / 12 \\
0 / 19\end{array}$ & Unidentified \\
\hline Bartholomew and Himes (1964) & Cell culture & $\begin{array}{l}\text { S/F } \\
\text { S/F } \\
\text { S/F }\end{array}$ & $\begin{array}{l}\text { RA } \\
\text { Reiter's } \\
\text { Control }\end{array}$ & $\left.\begin{array}{l}5 / 7 \\
3 / 4 \\
0 / 6\end{array}\right\}$ & $\begin{array}{l}\text { At least } 4 \text { antigenic } \\
\text { groups }\end{array}$ \\
\hline $\begin{array}{l}\text { Claus, McEwen, Brunner, and } \\
\text { Tsamparlis (1964) }\end{array}$ & CF culture & $\begin{array}{l}\text { S/F } \\
\text { S/F } \\
\text { S/F } \\
\text { S/M } \\
\text { S/M } \\
\text { S/M }\end{array}$ & $\begin{array}{l}\text { RA } \\
\text { Reiter's } \\
\text { Control } \\
\text { RA } \\
\text { Reiter's } \\
\text { Control }\end{array}$ & $\begin{array}{l}0 / 8 \\
0 / 11 \\
0 / 11 \\
0 / 6 \\
2 / 8 \\
0 / 10\end{array}$ & $\begin{array}{l}- \\
\overline{-} \\
\text { Unidentified }\end{array}$ \\
\hline Bartholomew $(1965,1967)$ & Cell culture & $\begin{array}{l}\text { S/F } \\
\text { S/F } \\
\text { S/F }\end{array}$ & $\begin{array}{l}\text { RA } \\
\text { Reiter's } \\
\text { Control }\end{array}$ & $\begin{array}{l}6 / 7 \\
3 / 4 \\
0 / 7\end{array}$ & $\begin{array}{l}2 M . \text { hyorhinis } \\
1 M . \text { hominis } \\
1 M . \text { arthritidis } \\
-\end{array}$ \\
\hline $\begin{array}{l}\text { Barnett, Balduzzi, Vaughan, and } \\
\text { Morgan (1966) }\end{array}$ & Cell culture & $\begin{array}{l}\mathbf{S} / \mathbf{F} \text { and } \\
\mathbf{S} / \mathbf{M}\end{array}$ & RA & $0 / 17$ & - \\
\hline $\begin{array}{l}\text { Fahlberg, Moore, Redmond, and } \\
\text { Brewer (1966) }\end{array}$ & CF culture & $\begin{array}{l}\mathbf{S} / \mathbf{F} \\
\mathbf{S} / \mathbf{M}\end{array}$ & $\begin{array}{l}\text { RA } \\
\text { Control }\end{array}$ & $\left.\begin{array}{r}22 / 24 \\
2 / 14\end{array}\right\}$ & $\begin{array}{l}\text { Unidentified-10 anti- } \\
\text { genically } \\
\text { homogeneous }\end{array}$ \\
\hline Williams (1968) & CF culture & $\begin{array}{l}S / F \\
S / F\end{array}$ & $\begin{array}{l}\text { RA } \\
\text { Control }\end{array}$ & $\begin{array}{r}36 / 90 \\
5 / 26\end{array}$ & $\begin{array}{l}\text { M. fermentans } \\
1 \text { M. fermentans } \\
2 M . \text { hominis } \\
2 \text { Unidentified }\end{array}$ \\
\hline $\begin{array}{l}\text { Marcolongo, Carcassi, Bianco, } \\
\text { Bravi, Di Paolo, and Lunghetti } \\
\text { (1969) }\end{array}$ & CF culture & $\begin{array}{l}\text { S/F } \\
\text { S/F } \\
\text { S/M } \\
\text { S/M }\end{array}$ & $\begin{array}{l}\text { RA } \\
\text { Control } \\
\text { RA } \\
\text { Control }\end{array}$ & $\begin{array}{r}1 / 60 \\
0 / 10 \\
43 / 58 \\
0 / 10\end{array}$ & $\begin{array}{l}\text { Unidentified } \\
\overline{\text { Unidentified }}\end{array}$ \\
\hline $\begin{array}{l}\text { Fraser, Shirodaria, Haire, and } \\
\text { Middleton (1971) }\end{array}$ & $\begin{array}{l}\text { Cell culture } \\
\text { CF culture }\end{array}$ & $\begin{array}{l}\text { S/M } \\
\text { S/M } \\
\mathbf{S} / \mathbf{M}\end{array}$ & $\begin{array}{l}\text { RA } \\
\text { Control } \\
\text { RA }\end{array}$ & $\begin{array}{l}10 / 17 \\
1 / 5 \\
0 / 15\end{array}$ & $\begin{array}{l}\text { Unidentified } \\
\text { Unidentified } \\
-\end{array}$ \\
\hline $\begin{array}{l}\text { Jansson, Mäkisara, Vainio, Vainio, } \\
\text { Snellman, and Tuuri (1971a) } \\
\text { Jansson, Wallgren, Wegelius, and } \\
\text { Tuuri (1971b) }\end{array}$ & $\begin{array}{l}\text { CF culture } \\
\text { and egg } \\
\text { inoculation }\end{array}$ & $\begin{array}{l}\text { S/F and } \\
\text { S/M } \\
\mathbf{S} / \mathbf{F} \text { and } \\
\mathbf{S} / \mathbf{M} \\
\mathbf{S} / \mathbf{F}\end{array}$ & $\begin{array}{l}\text { RA } \\
\text { Control } \\
\text { JRA }\end{array}$ & $\left.\begin{array}{c}40 / 88 \\
0 / 24 \\
2 / 2\end{array}\right\}$ & $\begin{array}{l}\text { Mostly small colonies } \\
\text { serologically related } \\
\text { to } M \text {. arthritidis }\end{array}$ \\
\hline
\end{tabular}


All the media, excluding $(a)$ and $(e)$, contained yeast extract prepared according to the method of Hers (Marmion, 1967). Media $(a),(b),(c),(d),(e)$, and $(f)$ were subcultured onto PPLO agar supplemented as for liquid medium $(f)$. The solid medium used for cultures from medium $(g)$ also contained $20 \%(\mathrm{v} / \mathrm{v})$ pancreatic digest of bovine lung; that from $(h)$ was equivalent to the broth with the exclusion of the egg yolk.

Details of the serum and atmospheric conditions of incubation for the various series of specimens are shown in Table II. The media used in series 2 and 3 did not contain any inhibitors.

These media were designed primarily to grow 'large colony' mycoplasmas rather than T-strains; the latter would have grown on some of the media without inhibitors and with anaerobic incubation.*

\section{Other tests}

(1) Some suspensions of synovial membrane in series 1 were inoculated directly onto supplemented PPLO agar plus horse serum and incubated aerobically, anaerobically, or in $10 \% \mathrm{CO}_{2}$ in air.

(2) 15 specimens of synovial fluid were frozen and thawed before inoculation into liquid medium (series 2).

(3) Cell cultures of synovial fluids (Mackay, Panayi, Neill, Robinson, Smith, Marmion, and Duthie, 1974) and cell cultures of synovial membranes prepared by trypsinization, in a similar manner to that described by Grayzel and Beck (1970), were also examined for mycoplasmas (series 4).

(4) Metabolic inhibition tests were carried out on sera from patients with rheumatoid arthritis and, as controls, on sera from patients with chronic bronchitis. The controls were matched for age and sex, and the blood samples

* Detailed information regarding the media may be obtained from S.M.S. were collected shortly after those from the rheumatoid patients. Mycoplasma hyorhinis and M. fermentans were used as the test organisms.

\section{Results}

Liquid or semi-solid medium cultures of synovial membrane and synovial fluid

Table II shows the type of media and the atmospheric conditions of incubation of the subcultures on solid medium, and the number of specimens examined from patients with rheumatoid arthritis, with Reiter's syndrome, and with other conditions (non-RA) in each of the 5 series of experiments together with the dates of starting and finishing.

Of a total of 133 examinations of 88 synovial membranes and 139 examinations of 119 synovial fluids from RA patients, only one yielded a culture of mycoplasma. This was a specimen of synovial membrane from a seropositive patient and it had been cultured in Eagle-Hanks tryptose phosphate broth with swine serum. The isolate was shown to be $M$. hyorhinis, a species from swine that could have been introduced with the swine serum used in the medium. No mycoplasmas were isolated from any of the other examinations of specimens from patients with rheumatoid arthritis, nor from the 18 examinations of 15 fluids from twelve patients with Reiter's syndrome, nor from the 28 examinations of 19 membranes and 44 examinations of 34 fluids from non-rheumatoid patients.

Small bodies were seen on and in the egg yolk PPLO agar medium used in series 5 , recalling the colonies

Table II Details of liquid and semi-solid media and number of specimens tested in the 5 series

\begin{tabular}{|c|c|c|c|c|c|c|c|c|c|}
\hline \multirow{2}{*}{$\begin{array}{l}\text { Series } \\
\text { no. }\end{array}$} & \multirow{2}{*}{$\begin{array}{l}\text { Liquid or semi- } \\
\text { solid medium }\end{array}$} & \multirow{2}{*}{$\begin{array}{l}\text { Serum in } \\
\text { medium }\end{array}$} & \multirow[b]{2}{*}{ Atmosphere* } & \multicolumn{2}{|c|}{ Synovial membranes } & \multicolumn{3}{|c|}{ Synovial fluids } & \multirow{2}{*}{$\begin{array}{l}\text { Period of } \\
\text { investigation }\end{array}$} \\
\hline & & & & $R A \dagger$ & Non-RA† & $R A \dagger$ & Reiter's & Non-RA† & \\
\hline 1 & $\begin{array}{l}\text { Eagle-Hanks } \\
\text { Semi-solid agar }\end{array}$ & $\begin{array}{l}\text { Swine } \\
\text { Swine }\end{array}$ & $\begin{array}{l}\text { Aerobic } \\
\text { Aerobic }\end{array}$ & $\begin{array}{r}12 \\
9\end{array}$ & $\begin{array}{l}1 \\
0\end{array}$ & $\begin{array}{l}0 \\
0\end{array}$ & $\begin{array}{l}0 \\
0\end{array}$ & $\begin{array}{l}0 \\
0\end{array}$ & $\begin{array}{r}25 \text { Feb 1964- } \\
30 \text { June } 1964\end{array}$ \\
\hline \multirow[t]{2}{*}{2} & $\left.\begin{array}{l}\text { Eagle-Hanks } \\
\text { Eagle-Hanks } \\
\text { Eagle-Hanks } \\
\text { PPLO broth } \times 2 \\
\text { PPLO broth } \times 2 \\
\quad+2 \% \mathrm{NaCl}\end{array}\right\}$ & $\begin{array}{l}\text { Horse } \\
\text { Swine } \\
\text { Human } \\
\text { Human } \\
\text { Human }\end{array}$ & $\begin{array}{l}10 \% \mathrm{CO}_{2} / \text { air } \\
10 \% \mathrm{CO}_{2} / \text { air } \\
10 \% \mathrm{CO}_{2} / \text { air } \\
10 \% \mathrm{CO}_{2} / \text { air } \\
10 \% \mathrm{CO}_{2} / \text { air }\end{array}$ & $\begin{array}{r}7 \\
18 \\
22 \\
0 \\
14\end{array}$ & $\begin{array}{l}6 \\
4 \\
9 \\
0 \\
3\end{array}$ & $\begin{array}{r}0 \\
0 \\
0 \\
54 \\
22\end{array}$ & $\begin{array}{r}0 \\
0 \\
0 \\
10 \\
3\end{array}$ & $\begin{array}{r}0 \\
0 \\
0 \\
19 \\
7\end{array}$ & $\begin{array}{l}16 \text { Nov } 1965- \\
13 \text { Feb } 1968\end{array}$ \\
\hline & $\begin{array}{l}\text { Heated blood broth } \\
\text { Bullock heart } \\
\text { Semi-solid agar }\end{array}$ & $\begin{array}{l}\text { Horse (blood) } \\
\text { Horse } \\
\text { Human }\end{array}$ & $\begin{array}{l}10 \% \mathrm{CO}_{2} / \text { air } \\
10 \% \mathrm{CO}_{2} / \text { air } \\
10 \% \mathrm{CO}_{2} / \text { air }\end{array}$ & $\begin{array}{r}20 \\
4 \\
0\end{array}$ & $\begin{array}{l}3 \\
2 \\
0\end{array}$ & $\begin{array}{r}26 \\
10 \\
8\end{array}$ & $\begin{array}{l}2 \\
0 \\
2\end{array}$ & $\begin{array}{l}8 \\
1 \\
4\end{array}$ & \\
\hline 3 & $\begin{array}{l}\text { Eagle-Hanks } \\
\text { PPLO } \times 2 \\
\quad+0.5 \% \text { Tween } 80 \\
\end{array}$ & $\begin{array}{l}\text { Human } \\
\text { Human }\end{array}$ & $\begin{array}{l}10 \% \mathrm{CO}_{2} / \text { air } \\
10 \% \mathrm{CO}_{2} / \text { air }\end{array}$ & $\begin{array}{l}17 \\
10\end{array}$ & $\begin{array}{l}0 \\
0\end{array}$ & $\begin{array}{l}\mathbf{0} \\
\mathbf{0}\end{array}$ & $\begin{array}{l}0 \\
0\end{array}$ & $\begin{array}{l}\mathbf{0} \\
\mathbf{0}\end{array}$ & $\begin{array}{l}1 \text { Oct } 1969- \\
11 \text { Feb } 1970\end{array}$ \\
\hline 4 & Diphasic & Horse & $\begin{array}{c}\text { Aerobic and } \\
\text { anaerobic }\end{array}$ & 0 & 0 & 12 & 1 & 4 & $\begin{array}{l}5 \text { Jan } 1972- \\
22 \text { Feb } 1972\end{array}$ \\
\hline 5 & $\begin{array}{c}\text { Brain heart infusion } \\
\text { broth + egg yolk }\end{array}$ & Human & Anaerobic & 0 & 0 & 7 & 0 & 1 & $\begin{array}{l}12 \text { Apr 1972- } \\
28 \text { Apr } 1972\end{array}$ \\
\hline \multicolumn{4}{|c|}{ Total no. of examinations } & 133 & 28 & 139 & 18 & 44 & \\
\hline \multicolumn{4}{|c|}{ Total no. of specimens examined } & 88 & 19 & 119 & $\overline{15}$ & 34 & \\
\hline
\end{tabular}


described by Jansson (1971); but similar bodies were seen on and in medium inoculated from control egg yolk broth.

Direct inoculation of synovial membrane suspension onto supplemented PPLO medium

In series 1 and 3, 59 suspensions of synovial membrane from patients with rheumatoid arthritis and 12 from patients with non-rheumatoid conditions were inoculated directly onto plates containing supplemented PPLO medium with horse serum (series 1) or human serum (series 3). Of the 59 rheumatoid specimens, 26 were incubated aerobically, 8 anaerobically, and 25 in $10 \% \mathrm{CO}_{2}$ in air; 8 of the non-rheumatoid specimens were incubated aerobically and 4 anaerobically. In no case was a mycoplasma isolated.

\section{Effect of freezing and thawing on the isolations from} synovial fluids

Fifteen specimens of synovial fluid (in series 2) from patients with rheumatoid arthritis were frozen and thawed before being inoculated. 4 of these were inoculated into double strength supplemented PPLO broth and 11 into semi-solid PPLO agar. In all cases human serum was used and subcultures were incubated in $10 \% \mathrm{CO}_{2}$ in air. No mycoplasmas were isolated.

Aerobic and anaerobic cultures of cells and supernatants from cell cultures from synovial fluids and synovial membranes

No mycoplasmas were isolated from cultures of the cells or the fluid phase of cell cultures established from 9 synovial fluid specimens from patients with rheumatoid arthritis, nor from two sets of specimens from non-rheumatoid patients. Direct inoculation of the cell deposits from the synovial fluids onto supplemented PPLO medium also failed to yield mycoplasmas. Similarly, no mycoplasmas were isolated from the cell cultures of 7 synovial membranes from six patients with rheumatoid arthritis.

Subcultures from PPLO egg yolk broth into fresh egg yolk broth

No mycoplasmas were isolated on solid medium from PPLO egg yolk broth subcultures from the initial PPLO egg yolk broths inoculated with synovial fluid from four patients with rheumatoid arthritis (series 5).

\section{Metabolic inhibition tests}

Table III shows the metabolic inhibiting titres in the sera from rheumatoid and non-rheumatoid patients using $M$. hyorhinis and $M$. fermentans as antigens. There was no significant difference in the distribution of antibody titres between the sera originating from rheumatoid and non-rheumatoid patients.

\section{Discussion}

Mycoplasmas are present as commensals in humans (Edward and Freundt, 1969) and at least one strain (Mycoplasma pneumoniae) is known to be pathogenic. They also occur widely both as commensals and as pathogens in a variety of animals (Edward and Freundt, 1969).

They are frequently found as contaminants in cell cultures (Hayflick, 1965; Stanbridge, 1971). They may come from the medium constituents, from the original cell line, from contamination of the cell line with other cells carrying mycoplasmas, or from the handlers. Therefore, the reports of isolations of mycoplasmas after the inoculation of cell cultures with specimens from patients with rheumatoid arthritis must be treated with reserve. Most authors who have used cells for isolation of mycoplasmas acknowledge this fact. Even though control cell cultures do not yield mycoplasmas, it is possible that the addition of clinical tissue specimens may increase the population of mycoplasmas already present in the cell culture and allow growth on sub-cultivation to cell-free medium. Fraser and others (1971) isolated mycoplasmas from 10 synovial cell cultures from RA patients and from one cell culture from a patient with another condition. The isolates were tentatively identified as Mycoplasma laidlawii and M. hyorhinis. These species were found as cell culture contaminants (Barile and Kern, 1971; Stanbridge, 1971). A subsequent epidemiological analysis of the dates of isolation of the mycoplasmas provided circumstantial evidence of cross-contamination from cell lines introduced into the laboratory, unsuspectingly carrying these mycoplasmas (K. B. Fraser, personal communication, 1973). Nevertheless, it is recognized that

Table III Results of metabolic inhibition tests on sera from patients with rheumatoid arthritis $(R A)$ and nonrheumatoid conditions (non-RA)

\begin{tabular}{|c|c|c|c|c|c|c|c|c|c|}
\hline \multirow[b]{2}{*}{ Test organism } & \multirow[b]{2}{*}{ Diagnosis } & \multirow{2}{*}{$\begin{array}{l}\text { No. of } \\
\text { sera tested }\end{array}$} & \multicolumn{7}{|c|}{ Metabolic inhibition titre-reciprocal } \\
\hline & & & $<6$ & 6 & 12 & 24 & 48 & 96 & $>96$ \\
\hline M. hyorhinis & $\begin{array}{l}\text { RA } \\
\text { Non-RA }\end{array}$ & $\begin{array}{l}20 \\
20\end{array}$ & $\begin{array}{l}4 \\
7\end{array}$ & $\begin{array}{l}5 \\
5\end{array}$ & $\begin{array}{l}6 \\
2\end{array}$ & $\begin{array}{l}2 \\
2\end{array}$ & $\begin{array}{l}0 \\
1\end{array}$ & $\begin{array}{l}3 \\
1\end{array}$ & $\begin{array}{l}0 \\
2\end{array}$ \\
\hline M. fermentans & $\begin{array}{l}\text { RA } \\
\text { Non-RA }\end{array}$ & $\begin{array}{r}12 \\
7\end{array}$ & $\begin{array}{r}12 \\
6\end{array}$ & $\begin{array}{l}0 \\
0\end{array}$ & $\begin{array}{l}0 \\
1\end{array}$ & $\begin{array}{l}\mathbf{0} \\
\mathbf{0}\end{array}$ & $\begin{array}{l}\mathbf{0} \\
\mathbf{0}\end{array}$ & $\begin{array}{l}\mathbf{0} \\
0\end{array}$ & $\begin{array}{l}0 \\
0\end{array}$ \\
\hline
\end{tabular}


there are mycoplasmas that will grow in cell culture systems and only poorly or not at all in cell-free media; see for example the history of the isolation of Mycoplasma suipneumoniae (Goodwin and Whittlestone, 1966).

Most of the investigations with cultures of rheumatoid synovial fluid or membrane direct onto cell-free culture media have been concerned with small numbers of specimens; in most the few isolates were not identified (see Table I). The synovium and its blood vessels are recognized to be effective traps or filters for particles circulating in the blood, e.g. immune complexes, bacteria, and the presence of antigenically diverse mycoplasmas in small numbers of specimens might be explained on that basis. However, the findings in two published series, namely those of Williams (1968) and Jansson and her co-workers (1971a), of a single antigenic type of mycoplasma in a high proportion of RA cases compared with controls is not easily dismissed with such an explanation.

Williams (1968) isolated M. fermentans from $40 \%$ of 90 specimens from patients with rheumatoid arthritis, but from only one of 26 specimens of control material, though other serotypes of mycoplasma were isolated from 4 other specimens of control material. $\mathrm{He}$ also reported metabolic inhibiting antibodies to M. fermentans in $72 \%$ of rheumatoid patients with rheumatoid factor, and in $36 \%$ of seronegative rheumatoid patients, and $28 \%$ of persons without RA. Further presumptive evidence of the involvement of $M$. fermentans in rheumatoid arthritis was that the migration of leucocytes taken from rheumatoid patients was inhibited in the presence of $M$. fermentans antigen (Williams, Brostoff, and Roitt, 1970; Williams and Bruckner, 1971).

The present work included methods that would be expected to isolate strains of $M$. fermentans, though the method of sucrose density gradient treatment of the specimens was not used in our investigations. The failure to isolate $M$. fermentans is in accord with the recent negative reports of Cole, Ward and Smith (1973), and Windsor, Nicholls, Maini, Edward, Lemcke, and Dumonde (1974), who did use a preliminary gradient centrifugation, and also those of Mardh, Nilsson, and Bjelle (1973). We have no explanation for the discrepancy between the original positive reports of Williams and the negative findings in this and other studies, but the role of $M$. fermentans in RA must surely be regarded as 'non proven'.

Jansson's early work (Jansson and Wager, 1967) reported the isolation of large-colony strains of $M$. arthritidis. In later series, small-colony isolates were reported (Jansson and others 1971a); these were serologically related to $M$. arthritidis. Similar smallcolony mycoplasmas were isolated from leukaemic bone marrow (Jansson, Vainio, and Tuuri, 1971c). The small colonies described by Jansson are of a very special nature and are unlikely to be detected with conventional media examined under the low power of $\frac{\mathrm{C}}{\mathrm{N}}$ the microscope. It would probably be necessary to have greater experience of handling these special vari- $\overrightarrow{\bar{s}}$ ants before recognizing them on isolation from speci- mens. Though we used a similar method and medium as Jansson for the examination of some of our specimens, we did not see any clear-cut examples of colonies similar to those described by her. Though there were structures that resembled small-colony mycoplasmas, these did not produce colonies on subculture, and similar bodies were seen both on the surface and in the medium of plates inoculated with control uninfected broths. The results described by Jansson are interesting, but our methods and experience were not adequate to confirm or refute Jansson's findings; we feel that some additional attribute to simple morphological identification, e.g. incorporation of radioactive isotope labelled precursors into the colonies or immunofluorescence with $M$. arthritidis antiserum, would be required for a confident identification of these special structures as mycoplasmas.

The establishment of cells from synovial membranes and fluids in culture may have the advantage of diluting antibody in the tissues which may be inhibitory to the mycoplasmas. But in spite of using this method in some of the present series and also culturing dilutions of synovial fluids and synovial membrane suspensions, no mycoplasmas were isolated.

The failure to show any difference in the range of metabolic-inhibiting antibodies against $M$. fermentans in patients with rheumatoid arthritis and in control subjects is in accord with results reported by Chanock, Purcell, and Decker (1967) and Mardh and others (1973), though they are at variance with those reported by Williams (1968). The range of titres in sera from control subjects in the present series was similar to that found by Mardh and others (1973). Chanock and others (1967) also found no difference in the two series of sera using $M$. hyorhinis as the test organism.

Since Sabin's early report of the association of mycoplasmas with a chronic arthritis in mice (1939a), many attempts have been made to show that these organisms play an aetiological role in rheumatoid arthritis in humans. The fact that many mycoplasmas are difficult to isolate on artificial culture medium means that negative results must be treated with caution. Nevertheless, the absence of confirmation, in this and other series, of the findings of the more impressive series reported in the literature casts much doubt on the aetiological role of conventional mycoplasmas in rheumatoid arthritis.

\section{Summary}

Attempts were made, using a variety of culture media, to isolate mycoplasma from 88 synovial membranes and 119 synovial fluids from patients with definite rheumatoid arthritis. M. hyorhinis was isolated from one culture of a synovial membrane, but the medium, 
which contained swine serum, may have been the source of the organism. No other mycoplasmas were isolated from the rheumatoid specimens examined, nor from 19 membranes and 34 fluids from patients with non-rheumatoid conditions, nor from 15 fluids from patients with Reiter's disease. Though an unconventional type of mycoplasma may be shown to be involved in the aetiology of rheumatoid arthritis, this has yet to be substantiated.

The authors thank the clinicians of the Rheumatic Diseases Unit, Northern General Hospital, Edinburgh, for the collection of synovial fluids, and the surgical team at the Princess Margaret Rose Hospital, Edinburgh, led by the late Mr. D. D. Savill, for the collection of membrane specimens. Technical assistance was given by staff of the Mycoplasma Unit, City Hospital, Edinburgh, and of the Department of Bacteriology, University of Edinburgh, and secretarial assistance by Mrs. V. McGrath. The strain of $M$. hyorhinis was identified by Dr. D. Taylor-Robinson. Dr. Elizabeth Robertson, Blood Transfusion Service, Edinburgh kindly collected the human blood.

The research was supported by grants from the Medical Research Council, the Arthritis and Rheumatism Council, and the Nuffield Foundation.

\section{References}

American Rheumatism Association (1959) Ann. rheum. Dis., 18, 49 (Diagnostic criteria for rheumatoid arthritis, 1958 revision)

Arai, M., Ishikawa, A., AND HotTA, E. (1964) In 'Proceedings of the 8th Congress of the Japanese Rheumatism Association', p. 279. Okayama, Japan.

Barile, M. F., AND KeRn, J. (1971) Proc. Soc. exp. Biol. (N.Y.), 138, 432 (Isolation of Mycoplasma arginini from commercial bovine sera and its implication in contaminated cell cultures)

Barnett, E. V., Balduzzi, P., Vaughan, J. H., and Morgan, H. R. (1966) Arthr. and Rheum., 9, 720 (Search for infectious agents in rheumatoid arthritis)

BARTHOLOMEW, L. E. (1965) Ibid., 8, 376 (Isolation and characterization of mycoplasmas (PPLO) from patients with rheumatoid arthritis, systemic lupus erythematosus and Reiter's syndrome)

- (1967) Ann. N.Y. Acad. Sci., 143, 522 (Characterization of mycoplasma strains and antibody studies from patients with rheumatoid arthritis)

- , AND Himes, J. (1964) Arthr. and Rheum., 7, 291 (Isolation of mycoplasma (PPLO) from patients with rheumatoid arthritis, systemic lupus erythematosus and Reiter's syndrome)

British Medical Journal (1965) 1, 607 (Is rheumatoid arthritis an infection?)

Buchanan, W. W., AND Dick, W. C. (1972) Med. Lab. Tech., 29, 109 (Rheumatoid arthritis-current thoughts on aetiology and pathogenesis)

Chanock, R. M., Purcell, R. H., And Decker, J. L. (1967). 'Mycoplasmas and rheumatoid arthritis', in '3rd Nuffield Conference on Rheumatism', p. 18.1. The Nuffield Foundation, London

Claus, G., McEwen, C., Brunner, T., and Tsamparlis, G. (1964) Brit. J. vener. Dis., 40, 170 (Microbiological studies of Reiter's disease)

Cole, B. C., Ward, J. R., AND Smith, C. B. (1973) Arthr. and Rheum., 16, 191 (Studies on the infectious etiology of rheumatoid arthritis)

Edward, D. G. F., AND Freundt, E. A. (1969) 'Classification of the mycoplasmatales', in 'The Mycoplasmatales and the L-phase of Bacteria', ed. L. Hayflick, p. 147. North Holland, Amsterdam

FAHLberg, W. J., MOORE, R. W., Redmond, H. E., AND BReWer, E. G., JR. (1966) Bact. Proc., 66, 48 (Isolation of mycoplasmas from human synovial fluids and tissues)

FORD, D. K. (1963) Arthr. and Rheum., 6, 159 (Rheumatoid arthritis-an infection?)

- (1968) Med. Clin. N. Amer., 52, 673 (Evidence for an infectious etiology of rheumatoid arthritis)

Fraser, K. B., Shirodaria, P. V., Haire, M., ANd Middleton, D. (1971) J. Hyg. (Lond.), 69, 17 (Mycoplasmas in cell cultures from rheumatoid synovial membranes)

Goodwin, R. F. W., AND Whittlestone, P. (1966) Brit. J. exp. Path., 47, 518 (Enzootic pneumonia of pigs: growth and behaviour of the causal mycoplasma in liquid media)

Grayzel, A. I., AND BeCK, C. (1970) J. exp. Med., 131, 367 (Rubella infection of synovial cells and the resistance of cells derived from patients with rheumatoid arthritis)

HAYFLICK, L. (1965) Texas Rep. Biol. Med., 23, Suppl. 1, 285 (Tissue cultures and mycoplasmas)

HiLl, A. G. S. (1968) Proc. roy. Soc. Med., 61, 971 (The role of infection in the causation of rheumatoid arthritis)

JansSon, E. (1971) J. clin. Path., 24, 53 (Isolation of fastidious mycoplasma from human sources)

- Mäkisara, P., Vainio, K., Vaino, U., Snellman, O., ANd TuUri, S. (1971a) Ann. rheum. Dis., 30, 506 (An 8-year study of mycoplasma in rheumatoid arthritis)

- - VAINIO, U., AND TUURI, S. (1971c) Acta rheum. scand., 17, 223 (Cultivation of a mycoplasma from the bone marrow in systemic lupus erythematosus disseminatus)

- , AND WAGER, O. (1967) Ann. N.Y. Acad. Sci., 143, 535 (Mycoplasma in collagen diseases and blood dyscrasia)

—, Wallgren, G. R., Wegelius, R., AND TuURI, S. (1971b) Acta rheum. scand., 17, 268 (Mycoplasma in juvenile rheumatoid arthritis)

Jonsson, J. (1961) Ibid., 7, 287 (Mycoplasma organisms in synovial fluid from rheumatic joints)

Lancet (1970) 2, 303 (Aetiology of rheumatoid arthritis) 
MACKAY, J. M. K. (1966) 'Association of pleuropneumonia-like organisms (PPLO) with pulmonary adenomatosis in sheep-cultural and serological findings', in 'Lung Tumours in Animals. Proceedings of the 3rd Quadrennial International Conference on Cancer', ed. L. Severi, p. 403. Division of Cancer Research, University of Perugia.

—, Panayi, G., Neill, W. A., Robinson, A., Smith, W., Marmion, B. P., and Duthie, J. J. R. (1974) Ann. rheum. Dis., 33, 225 (Cytology of rheumatoid synovial cells in culture. I. Composition and sequence of cell populations in cultures of rheumatoid synovial fluid)

Marcolongo, R., JR., Carcassi, A., Bianco, G., Bravi, A., Di Paolo, N., and lunghetti, R. (1969) Boll. Ist. Sieroter. Milan, 48, 363 (Isolation of mycoplasma and antibody studies from patients with rheumatoid arthritis)

Mardh, P. A., Nilsson, F. J., AND Bjelle, A. (1973) Ann. rheum. Dis., 32, 319 (Mycoplasmas and bacteria in synovial fluid from patients with arthritis)

MARMION, B. P. (1967) 'The mycoplasmas: new information on their properties and their pathogenicity for man', in 'Recent Advances in Medical Microbiology', ed. A. P. Waterson, p. 170. Churchill, London

Purcell, R. H., Taylor-Robinson, D., Wong, D. C., and Chanock, R. M. (1966) Amer. J. Epidemiol., 84, 51 (A color test for the measurement of antibody to the non-acid forming human mycoplasma species)

Ross, R. F., AND SwITZER, W. P. (1968) Med. Clin. N. Amer., 52, 677 (Mycoplasmal arthritis of swine: a possible model for rheumatoid arthritis)

SABIN, A. B. (1939a) Science, 89, 228 (Experimental proliferative arthritis in mice produced by filtrable pleuropneumonia-like microorganisms)

- (1939b) Ibid., 90, 18 (Mice as carriers of pathogenic pleuropneumonia-like microorganisms)

- AND WARREN, J. (1940) J. Bact., 40, 823 (The curative effect of certain gold compounds on experimental proliferative chronic arthritis in mice)

SHARP, J. T. (1964) Arthr. and Rheum., 7, 437 (The mycoplasmataceae (PPLO) as causes of joint infections)

- AND RigGs, S. (1967) ‘Mycoplasmas and rheumatic disease,' in 'Rheumatology,' ed. J. Rotstein, vol. 1, p. 51. Karger, Basle

Smiley, J. D., SAChS, C., AND ZIFF, M. (1968) J. clin. Invest., 47, 624 (In vitro synthesis of immunoglobulin by rheumatoid synovial membrane)

Stanbridge, E. (1971) Bact. Rev., 35, 206 (Mycoplasmas and cell cultures)

StewART, S. M., AND ChOWdRAY, J. E. (1968) J. path. Bact., 95, 580. (Isolation of mycoplasmas from the human respiratory tract)

—, AleXander, W. R. M., AND Duthie, J. J. R. (1969) Ann. rheum. Dis., 28, 477 (Isolation of diphtheroid bacilli from synovial membrane and fluid in rheumatoid arthritis)

Taylor-Robinson, D., Purcell, R. H., Wong, D. C., AND Chanock, R. M. (1966) J. Hyg. (Lond.), 64, 91 (A colour test for the measurement of antibody to certain mycoplasma species based upon the inhibition of acid production)

Wruliams, M. H. (1968) In 'Rheumatic Diseases', ed. J. J. R. Duthie and W. R. M. Alexander, p. 171. University Press, Edinburgh. (University of Edinburgh Pfizer Medical Monographs 3)

-, Brostoff, J., AND RortT, I. M. (1970) Lancet, 2, 277 (Possible role of Mycoplasma fermentans in pathogenesis of rheumatoid arthritis)

—, AND BRUCKNER, F. E. (1971) Ann. rheum. Dis., 30, 271 (Immunological reactivity to Mycoplasma fermentans in patients with rheumatoid arthritis)

Windsor, G. D., Nicholls, A., Maini, R. N., Edward D. G. FF., Lemcke, R. M., and Dumonde, D. C. (1974) Ibid., 33, 70 (Search for mycoplasma in synovial fluids from patients with rheumatoid arthritis) 